\title{
MOTIVASI BELAJAR SISWA SMA DALAM PEMBELAJARAN MATEMATIKA DENGAN MODEL BRAIN BASED LEARNING
}

\author{
Kiki Nia Sania Effendi \\ Pendidikan Matematika FKIP Universitas Singaperbangsa Karawang \\ kiki.niasania@staff.unsika.ac.id \\ Rina Marlina \\ Pendidikan Matematika FKIP Universitas Singaperbangsa Karawang
}

\begin{abstract}
Abstrak
Penelitian ini dilatarbelakangi dengan motivasi belajar siswa SMA dalam pembelajaran matematika. Tujuan penelitian ini untuk mengetahui motivasi belajar siswa SMA dalam pembelajaran matematika dengan model Brain Based Learning.. penelitian ini merupakan penelitian kuantitatif metode deskriptif. Hasil penelitian menunjukkan motivasi belajar siswa pada kriteria baik terlihat dari persentase dari hasil skala motivasi siswa dari setiap indikator didominasi oleh persentase yang berada pada $51 \%-75 \%$.
\end{abstract}

Kata Kunci: Motivasi Belajar, Pembelajaran Matematika, Model Brain Based Learning.

\begin{abstract}
This research is motivated by the motivation to learn high school students in learning mathematics. The purpose of this study was to determine high school students' motivation in learning mathematics with the Brain Based Learning model. This research is a quantitative method of descriptive research. The results showed that students' learning motivation on good criteria was seen from the percentage of the results of the student motivation scale of each indicator dominated by the percentage that was at $51 \%-75 \%$.
\end{abstract}

Keywords: Learning Motivation, Mathematics Learning, Brain Based Learning Model.

\section{PENDAHULUAN}

Matematika sebagai ilmu pengetahuan yang ada dalam mata pelajaran di sekolah dan memiliki hubungan dengan keseharian siswa, maka matematika memiliki peranan yang sangat penting dalam kehidupan sehari-hari. Menurut Cockroft (Andriani dkk, 2016) mengemukakan bahwa matematika perlu diajarkan kepada siswa karena memiliki kugunaan disegala segi kehidupan, semua bidang studi memerlukan keterampilan matematika yang sesuai, sarana komunikasi yang kuat, singkat dan jelas, digunakan untuk menyajikan informasi dalam berbagai cara, meningkatkan kemampuan berpikir logis, ketelitian dan kesadaran kekurangan, memberikan kepuasan terhadap usaha memecahkan masalah yang menantang. Oleh karena itu dalam kehidupan sehari-hari penting mempelajari matematika, akan tetapi masih banyak siswa yang mengganggap matematika itu sulit. Dari hal tersebut terlihat motivasi siswa tersebut kurang untuk mempelajari matematika karena siswa mudah menyerah ketika menyelesaikan soal-soal matematika dan frekuensi mereka belajar matematika kurang. Mereka tidak belajar matematika dirumah bahkan pada saat disekolahpun mereka cenderung malas mengikuti pembelajaran matematika.

Menurut Puger (Syamarro, 2015) Motivasi adalah kekuatan, baik dalam diri maupun dari luar yang mendorong seseorang untuk mencapai tujuan tertentu yang telah ditetapkan sebelumnya. Ada tiga hal yang melatar belakangi motivasi seseorang menurut Mcleland (Fatchurrohman, 2011) The Need for Achievement (n-ach) (Kebutuhan akan Prestasi / Pencapaian), The Need for Authority and Power (n-pow) (Kebutuhan akan Kekuasaan), The Need for Affiliation (n-affil) (Kebutuhan akan Afiliasi / Keanggotaan). Selanjutnya Sardiman (2012) menjelaskan bahwa siswa dikatakan berhasil dalam belajar jika ada motivasi dari dirinya 
sendiri untuk belajar, sehingga ia mengetahui apa yang akan dipelajari dan memahami mengapa hal tersebut perlu untuk dipelajari. Pembelajaran matematika diperlukan adanya motivasi bagi siswa agar mereka mampu menguasai materi pembelajaran karena dengan motivasi siswa akan berjuang penuh semangat untuk belajar tanpa mengenal kata menyerah untuk menyelesaikan permasalahan matematika yang disajikan pada kegiatan pembelajaran.

Terkait dengan pentingnya motivasi belajar maka perlu ada pembenahan dalam proses pembelajaran matematika. Dengan keadaan siswa yang kurang aktif dalam proses pembelajaran, maka salah satu model pembelajaran yang dapat menumbuhkan motivasi belajar dan melatih kemampuan komunikasi matematis. Salah satu model pembelajaran yang bisa meningkatkan motivasi belajar dan kemampuan komunikasi matematis siswa adalah model pembelajaran Brain Based Learning. Menurut Duman (Sukonco dan Mahmudi, 2016) bahwa pembelajaran dengan model pembelajaran Brain Based Learning tidak hanya meningkatkan prestasi akademik tetapi juga memberikan motivasi yang baik bagi para siswa dan guru dengan adanya suasana kelas yang kondusif, usaha bersama, dan minat.

Faidi (2013) menyebutkan model Brain-Based Learning atau pembelajaran berbasis otak ialah pembelajaran yang merupakan lingkungan belajar, baik sekolah maupun luar sekolah, di mana fungsi otak dan peranannya dalam pembelajaran digunakan. Menurut Caine \& Caine (Sukonco dan Mahmudi, 2016) tujuan dari model pembelajaran Brain Based Learning adalah mengarahkan pembelajaran dari sekedar menghafal menjadi belajar bermakna. Ada tiga strategi utama yang dapat dikembangkan dalam pembelajaran dengan model pembelajaran Brain Based Learning ini Sapa'at (Syarwan, 2014) yakni: (1) menciptakan lingkungan belajar yang menantang kemampuan berpikir siswa; (2) menciptakan lingkungan pembelajaran yang menyenangkan; dan (3) menciptakan situasi pembelajaran yang aktif dan bermakna.
Model pembelajaran Brain Based Learning berpotensi dapat mengembangkan motivasi siswa. Hal ini didukung hasil penelitian Isro'i dan Ghufron (2015) bahwa pembelajaran matematika dengan Brain Based Learning efektif untuk meningkatkan motivasi dan prestasi belajar siswa.

\section{METODE}

Penelitian ini merupakan penelitian kualitatif dan menggunakan metode deskriptif. Penelitian deskriptif adalah penelitian yang dimaksudkan untuk menyelidiki keadaan, kondisi atau hal-hal lain yang sudah disebutkan, yang hasilnya dipaparkan dalam bentuk laporan penelitian (Arikunto, 2010). Pada penelitian deskriptif, peneliti tidak mengubah, menambah, atau mengadakan manipulasi terhadap objek atau wilayah penelitian. Selanjutnya, memaparkan apa yang terjadi dalam bentuk laporan penelitian secara lugas, seperti apa adanya.

Penelitian deskriptif dalam penelitian ini dimaksudkan untuk mendapatkan gambaran dan keterangan-keterangan mengenai motivasi belajar siswa dari proses pembelajaran dengan penerapan model Brain Based Learning dan pengisian skala motivasi. Subjek dalam penelitian ini adalah siswa kelas XI sebanyak 36 siswa disalah satu sekolah SMA di Kabupaten Karawang. Penelitian ini melakukan pengumpulan data untuk mendapatkan data yang lengkap guna mendukung keberhasilan dalam penelitian ini. Teknik yang digunakan yaitu skala motivasi dan dokumentasi. Penggunaan skala motivasi bertujuan untuk mengetahui bagaimana motivasi siswa. skala motivasi siswa menggunakan skala likert yang dinyatakan dalam salah satu kategori : SS (sangat setuju), S (setuju), N (netral), TS (tidak setuju), atau STS (sangat tidak setuju). Skala sikap dihitung pada pada setiap pernyataan berdasarka jawaban responden, sehingga diperoleh persentase dari setiap pernyataan. Kemudian, untuk menganalisis motivasi belajar menggunakan kriteria analisis deskriptif persentase yang dikemukakan oleh Riduwan (2004), yaitu: 
Tabel 1. Kriteria Analisis Deskriptif

\begin{tabular}{|c|c|}
\hline Persentase & Kriteria \\
\hline $76 \%-100 \%$ & Sangat Baik \\
\hline $51 \%-75 \%$ & Baik \\
\hline $26 \%-50 \%$ & Cukup Baik \\
\hline $1 \%-25 \%$ & Kurang Baik \\
\hline
\end{tabular}

\section{HASIL DAN PEMBAHASAN}

Hasil penelitian ini dilaksanakan di salah satu SMA di Kabupaten Karawang pada semester ganjil tahun ajaran 2019/2020. Penelitian dilakukan pada satu kelas yaitu kelas XI Mipa 6 dengan jumlah 36 siswa. Skala motivasi digunakan untuk mengetahui motivasi siswa terhadap pembelajaran matematika, motivasi belajar siswa terhadap pembelajaran matematika dengan model Brain Based Learning dalam pembelajaran matematika. Setelah data diolah dan memperoleh hasil maka penjelasan yang lebih berdasarkan indikator pada skala motivasi dapat dilihat pada tabeltabel berikut ini:

Tabel 2. Durasi Kegiatan Belajar

\begin{tabular}{|c|c|c|c|c|c|c|}
\hline No. pernyataan & Skor/ item & 1 & 2 & 3 & 4 & 5 \\
\hline \multirow{2}{*}{1} & Jumlah siswa & 0 & 1 & 2 & 5 & 28 \\
\cline { 2 - 7 } & Persentase & $0 \%$ & $3 \%$ & $6 \%$ & $14 \%$ & $78 \%$ \\
\hline \multirow{2}{*}{29} & Jumlah siswa & 0 & 2 & 3 & 7 & 24 \\
\cline { 2 - 7 } & Persentase & $0 \%$ & $6 \%$ & $8 \%$ & $19 \%$ & $67 \%$ \\
\hline
\end{tabular}

Berdasarkan Tabel 2 motivasi siswa dengan indikator durasi kegiatan belajar berada pada kriteria sangat baik. Persentase siswa yang setuju dan sangat setuju sebesar $14 \%$ dan $78 \%$ pada pernyataan positif, sehingga jika dijumlahkan hasilnya mencapai $92 \%$. Persentase siswa yang tidak setuju dan sangat tidak setuju sebesar 19\% dan $67 \%$ pada pernyataan negatif, sehingga jika dijumlahkan hasilnya mencapai $86 \%$.

Tabel 3. Frekuensi Kegiatan Belajar

\begin{tabular}{|c|c|c|c|c|c|c|}
\hline No. pernyataan & Skor/ item & 1 & 2 & 3 & 4 & 5 \\
\hline \multirow{2}{*}{2} & Jumlah siswa & 0 & 5 & 17 & 10 & 4 \\
\cline { 2 - 7 } & Persentase & $0 \%$ & $14 \%$ & $47 \%$ & $28 \%$ & $11 \%$ \\
\hline \multirow{2}{*}{27} & Jumlah siswa & 0 & 3 & 17 & 12 & 4 \\
\cline { 2 - 7 } & Persentase & $0 \%$ & $8 \%$ & $47 \%$ & $33 \%$ & $11 \%$ \\
\hline
\end{tabular}

Berdasarkan Tabel 3 motivasi siswa dengan indikator frekuensi kegiatan belajar berada pada kriteria cukup baik. Persentase siswa yang setuju dan sangat setuju sebesar $33 \%$ dan $11 \%$ pada pernyataan positif, sehingga jika dijumlahkan hasilnya mencapai $44 \%$. Persentase siswa yang tidak setuju dan sangat tidak setuju sebesar 28\% dan $11 \%$ pada pernyataan negatif, sehingga jika dijumlahkan hasilnya mencapai $39 \%$.

Tabel 4. Presistensi dalam Belajar

\begin{tabular}{|c|c|c|c|c|c|c|}
\hline No. pernyataan & Skor/ item & 1 & 2 & 3 & 4 & 5 \\
\hline \multirow{2}{*}{3} & Jumlah siswa & 1 & 1 & 12 & 19 & 3 \\
\cline { 2 - 7 } & Persentase & $3 \%$ & $3 \%$ & $33 \%$ & $53 \%$ & $8 \%$ \\
\hline \multirow{2}{*}{15} & Jumlah siswa & 2 & 5 & 9 & 15 & 5 \\
\cline { 2 - 7 } & Persentase & $5 \%$ & $14 \%$ & $25 \%$ & $42 \%$ & $14 \%$ \\
\hline
\end{tabular}

Berdasarkan Tabel 4 motivasi siswa dengan indikator presistensi kegiatan belajar berada pada kriteria baik. Persentase siswa yang setuju dan sangat setuju sebesar 53\% dan $8 \%$ pada pernyataan positif, sehingga jika dijumlahkan hasilnya mencapai $61 \%$. 
Persentase siswa yang tidak setuju dan sangat tidak setuju sebesar $42 \%$ dan $14 \%$ pada pernyataan negatif, sehingga jika dijumlahkan hasilnya mencapai $56 \%$.

Tabel 5. Ketabahan, keuletan dan kemampuan dalam menghadapi kegiatan dan kesulitan untuk mencapai tujuan

\begin{tabular}{|c|c|c|c|c|c|c|}
\hline No. pernyataan & Skor/ item & 1 & 2 & 3 & 4 & 5 \\
\hline \multirow{2}{*}{7} & Jumlah siswa & 0 & 2 & 16 & 15 & 3 \\
\cline { 2 - 7 } & Persentase & $0 \%$ & $6 \%$ & $44 \%$ & $42 \%$ & $8 \%$ \\
\hline \multirow{2}{*}{13} & Jumlah siswa & 0 & 2 & 19 & 11 & 4 \\
\cline { 2 - 7 } & Persentase & $0 \%$ & $6 \%$ & $53 \%$ & $31 \%$ & $11 \%$ \\
\hline \multirow{2}{*}{14} & Jumlah siswa & 2 & 3 & 9 & 7 & 15 \\
\cline { 2 - 7 } & Persentase & $6 \%$ & $8 \%$ & $25 \%$ & $19 \%$ & $42 \%$ \\
\hline \multirow{2}{*}{23} & Jumlah siswa & 3 & 4 & 17 & 9 & 3 \\
\cline { 2 - 7 } & Persentase & $8 \%$ & $11 \%$ & $47 \%$ & $25 \%$ & $8 \%$ \\
\hline
\end{tabular}

Berdasarkan Tabel 5 motivasi siswa dengan indikator ketabahan, keuletan dan kemampuan dalam menghadapi kegiatan dan kesulitan berada pada kriteria cukup baik. Persentase siswa yang setuju dan sangat setuju pada pertanyaan positif nomor 13 sebesar $31 \%$ dan $11 \%$ kemudian pada pernyataan positif nomor 23 sebesar $25 \%$ dan $8 \%$, sehingga jika dijumlahkan hasilnya mencapai $42 \%$ dan $33 \%$. Persentase siswa yang tidak setuju dan sangat tidak setuju pada pernyataan negatif nomor 7 sebesar $42 \%$ dan $8 \%$ dan pada pernyataan negatif nomor 14 sebanyak $19 \%$ dan $42 \%$, sehingga jika dijumlahkan hasilnya mencapai $50 \%$ dan $61 \%$.

Tabel 6. Pengabdian dan pengorbanan untuk mencapai tujuan

\begin{tabular}{|c|c|c|c|c|c|c|}
\hline No. Pernyataan & Skor/ item & 1 & 2 & 3 & 4 & 5 \\
\hline \multirow{2}{*}{8} & Jumlah siswa & 0 & 8 & 9 & 15 & 4 \\
\cline { 2 - 7 } & Persentase & $0 \%$ & $22 \%$ & $25 \%$ & $42 \%$ & $11 \%$ \\
\hline \multirow{2}{*}{26} & Jumlah siswa & 0 & 2 & 13 & 17 & 4 \\
\cline { 2 - 7 } & Persentase & $0 \%$ & $6 \%$ & $36 \%$ & $47 \%$ & $11 \%$ \\
\hline
\end{tabular}

Berdasarkan Tabel 6 motivasi siswa dengan indikator pengabdian dan pengorbanan berada pada kriteria baik. Persentase siswa yang setuju dan sangat setuju sebesar $47 \%$ dan $11 \%$ pada pernyataan positif, sehingga jika dijumlahkan hasilnya mencapai $58 \%$. Persentase siswa yang tidak setuju dan sangat tidak setuju sebesar $42 \%$ dan $11 \%$ pada pernyataan negatif, sehingga jika dijumlahkan hasilnya mencapai 53\%.

Tabel 7. Tingkatan aspirasi yang hendak dicapai dengan kegiatan yang dilakukan

\begin{tabular}{|c|c|c|c|c|c|c|}
\hline No. Pernyataan & Skor/ item & 1 & 2 & 3 & 4 & 5 \\
\hline \multirow{2}{*}{16} & Jumlah siswa & 0 & 4 & 13 & 15 & 4 \\
\cline { 2 - 7 } & Persentase & $0 \%$ & $11 \%$ & $36 \%$ & $42 \%$ & $11 \%$ \\
\hline \multirow{2}{*}{28} & Jumlah siswa & 0 & 1 & 6 & 7 & 22 \\
\cline { 2 - 7 } & Persentase & $0 \%$ & $3 \%$ & $17 \%$ & $19 \%$ & $61 \%$ \\
\hline
\end{tabular}

Berdasarkan Tabel 7 motivasi siswa dengan indikator tingkatan aspirasi yang hendak dicapai dengan kegiatan yang dilakukan berada pada kriteria baik. Persentase siswa yang setuju dan sangat setuju sebesar 19\% dan $61 \%$ pada pernyataan positif, sehingga jika dijumlahkan hasilnya mencapai $80 \%$. Persentase siswa yang tidak setuju dan sangat tidak setuju sebesar $42 \%$ dan $11 \%$ pada pernyataan negatif, sehingga jika dijumlahkan hasilnya mencapai 53\%. 
Tabel 8. Tingkat kualifikasi prestasi

\begin{tabular}{|c|c|c|c|c|c|c|}
\hline No. Pernyataan & Skor/ item & 1 & 2 & 3 & 4 & 5 \\
\hline \multirow{2}{*}{18} & Jumlah siswa & 0 & 1 & 23 & 7 & 5 \\
\cline { 2 - 7 } & Persentase & $0 \%$ & $3 \%$ & $64 \%$ & $19 \%$ & $14 \%$ \\
\hline \multirow{2}{*}{22} & Jumlah siswa & 0 & 4 & 20 & 9 & 3 \\
\cline { 2 - 7 } & Persentase & $0 \%$ & $11 \%$ & $56 \%$ & $25 \%$ & $8 \%$ \\
\hline
\end{tabular}

Berdasarkan Tabel 8 motivasi siswa dengan indikator tingkatan kualifikasi prestasi berada pada kriteria cukup baik. Persentase siswa yang setuju dan sangat setuju sebesar $25 \%$ dan $8 \%$ pada pernyataan positif, sehingga jika dijumlahkan hasilnya mencapai $33 \%$. Persentase siswa yang tidak setuju dan sangat tidak setuju sebesar 19\% dan $14 \%$ pada pernyataan negatif, sehingga jika dijumlahkan hasilnya mencapai $33 \%$.

Tabel 9. Arah sikap terhadap sasaran kegiatan

\begin{tabular}{|c|c|c|c|c|c|c|}
\hline No. Pernyataan & Skor/ item & 1 & 2 & 3 & 4 & 5 \\
\hline \multirow{2}{*}{4} & Jumlah siswa & 0 & 3 & 17 & 11 & 5 \\
\cline { 2 - 7 } & Persentase & $0 \%$ & $8 \%$ & $47 \%$ & $31 \%$ & $14 \%$ \\
\hline \multirow{2}{*}{17} & Jumlah siswa & 0 & 11 & 15 & 7 & 3 \\
\cline { 2 - 7 } & Persentase & $0 \%$ & $31 \%$ & $42 \%$ & $19 \%$ & $8 \%$ \\
\hline
\end{tabular}

Berdasarkan Tabel 9 motivasi siswa dengan indikator arah sikap terhadap sasaran kegiatan berada pada kriteria cukup baik. Persentase siswa yang setuju dan sangat setuju sebesar $19 \%$ dan $8 \%$ pada pernyataan positif, sehingga jika dijumlahkan hasilnya mencapai $28 \%$. Persentase siswa yang tidak setuju dan sangat tidak setuju sebesar 31\% dan $14 \%$ pada pernyataan negatif, sehingga jika dijumlahkan hasilnya mencapai $45 \%$.

Dalam skala motivasi ini, tidak hanya untuk mengetahui motivasi siswa terhadap pembelajaran matematika melainkan motivasi siswa terhadap pembelajaran matematika dengan model pembelajaran Brain Based Learning. Hasilnya menunjukan bahwa motivasi siswa pada pembelajaran matematika dengan model pembelajaran Brain Based Learning berada pada kriteria baik terlihat dari hasil persentase dari pernyataan pada skala motivasi didominasi pada persentase $51 \%$ $75 \%$. Adapun hasil dari masing-masing pernyataan dapat dilihat dari tabel 10 berikut ini :

Tabel 10. Menunjukan motivasi terhadap pembelajaran dengan model Brain Based Learning

\begin{tabular}{|c|c|c|c|c|c|c|}
\hline No. Pernyataan & Skor/ item & 1 & 2 & 3 & 4 & 5 \\
\hline \multirow{2}{*}{5} & Jumlah siswa & 0 & 6 & 14 & 14 & 2 \\
\cline { 2 - 7 } & Persentase & $0 \%$ & $17 \%$ & $39 \%$ & $39 \%$ & $6 \%$ \\
\hline \multirow{2}{*}{6} & Jumlah siswa & 0 & 2 & 22 & 6 & 6 \\
\cline { 2 - 7 } & Persentase & $0 \%$ & $6 \%$ & $61 \%$ & $17 \%$ & $17 \%$ \\
\hline \multirow{2}{*}{9} & Jumlah siswa & 0 & 2 & 14 & 17 & 3 \\
\cline { 2 - 7 } & Persentase & $0 \%$ & $6 \%$ & $39 \%$ & $47 \%$ & $8 \%$ \\
\hline \multirow{2}{*}{10} & Jumlah siswa & 0 & 1 & 10 & 10 & 15 \\
\cline { 2 - 7 } & Persentase & $0 \%$ & $3 \%$ & $28 \%$ & $28 \%$ & $42 \%$ \\
\hline \multirow{2}{*}{11} & Jumlah siswa & 0 & 3 & 9 & 6 & 18 \\
\cline { 2 - 7 } & Persentase & $0 \%$ & $8 \%$ & $25 \%$ & $17 \%$ & $50 \%$ \\
\hline \multirow{2}{*}{12} & Jumlah siswa & 3 & 2 & 3 & 13 & 15 \\
\cline { 2 - 7 } & Persentase & $8 \%$ & $6 \%$ & $8 \%$ & $36 \%$ & $42 \%$ \\
\hline
\end{tabular}




\begin{tabular}{|c|c|c|c|c|c|c|}
\hline \multirow{2}{*}{19} & Jumlah siswa & 0 & 0 & 11 & 20 & 5 \\
\cline { 2 - 7 } & Persentase & $0 \%$ & $0 \%$ & $31 \%$ & $56 \%$ & $14 \%$ \\
\hline \multirow{2}{*}{20} & Jumlah siswa & 1 & 4 & 13 & 15 & 3 \\
\cline { 2 - 7 } & Persentase & $3 \%$ & $11 \%$ & $36 \%$ & $42 \%$ & $8 \%$ \\
\hline \multirow{2}{*}{21} & Jumlah siswa & 0 & 1 & 14 & 13 & 8 \\
\cline { 2 - 7 } & Persentase & $0 \%$ & $3 \%$ & $39 \%$ & $36 \%$ & $22 \%$ \\
\hline 24 & Jumlah siswa & 0 & 1 & 13 & 14 & 8 \\
\hline \multirow{2}{*}{25} & Persentase & $0 \%$ & $3 \%$ & $36 \%$ & $39 \%$ & $22 \%$ \\
\hline \multirow{2}{*}{30} & Jumlah siswa & 1 & 5 & 5 & 16 & 9 \\
\cline { 2 - 7 } & Persentase & $3 \%$ & $14 \%$ & $14 \%$ & $44 \%$ & $25 \%$ \\
\hline & Jumlah siswa & 0 & 2 & 13 & 19 & 2 \\
\cline { 2 - 7 } & Persentase & $0 \%$ & $6 \%$ & $36 \%$ & $53 \%$ & $6 \%$ \\
\hline
\end{tabular}

Pada pelaksanaan penelitian ini, materi yang digunakan adalah program linear dua variabel yang meliputi menjelaskan pengertian program linear dua variabel, menjelaskan sistem pertidaksamaan dua variabel, menjelaskan nilai optimum dan menjelaskan penerapan program linear dalam kehidupan sehari-hari. Pada proses pembelajarannya siswa diberikan lembar kerja siswa (LKS). Proses pembelajaran siswa dikelas dikelompokan menjadi 6 kelompok yang setiap kelompoknya terdiri dari 6 siswa.

Pada pertemuan awal proses pembelajaran dengan model pembelajaran Brain Based Learning, siswa terlihat semangat dalam mengawali proses pembelajaran. Selanjutanya pada tahap pra pemaparan peserta didik diberikan ulasan atau permasalahan tentang pembelajaran materi program linear dengan berdiskusi dengan teman sekelasnya. Pada saat pemberian masalah siswa terlihat aktif mengajukan pertanyaan dan memberi tanggapan pada permasalahan yang ditampilkan. Pada saat pengerjaan lembar kerja siswa (LKS) terdapat beberapa siswa yang kesulitan dalam menyelesaikan permasalahan yang ada pada lembar kerja siswa (LKS), sehingga guru memberi bantuan pada siswa tersebut dengan memberi penjelasan terkait pertanyaan yang diajukan. Para siswa belum terbiasa menggunakan lembar kerja siswa (LKS) yang mengkontruksi pemahaman mereka. Kemudian pada tahap inkubasi dan memasukan memori, guru meminta siswa untuk membaca ulang materi dan hasil pengerjaannya pada buku pegangan siswa dan LKS sambil mendengarkan musik. Pada tahap ini siswa terlihat nyaman dalam belajar dan membaca kembali dengan rileks. Selanjutnya siswa diminta untuk mempresentasikan hasil belajarnya di depan kelas dan kemudian guru dan siswa lainnya memberikan apresiasi kepada siswa yang berani mempresentasikan belajajarnya. Pada tahap ini siswa terlihat bahagia dan antusias dalam proses belajar dan mengajarb sehingga hal inilah dapat berpengaruh pada motivasi belajar. Pebrinovita (2013) Motivasi belajar merupakan faktor psikis yang berperan penting dalam hal penumbuhan gairah, rasa senang, dan bersemangat siswa dalam belajar.

Pada pertemuan-pertemuan selanjutnya siswa mulai terbiasa mengikuti langkah pembelajaran model pembelajaran Brain Based Learning dan antusias mengikuti pembelajaran. Siswa terlihat lebih aktif dalam proses pembelajaran khususnya pada proses penyelesaian masalah. Siswa berani mengajukan pertanyaan dan aktif memberikan tanggapan saat proses pembelajaran berlangsung. Kemudian siswa memiliki semangat untuk mempresentasikan hasil pekerjaannya. Salah satu faktor yang mempengaruhi motivasi belajar siswa yaitu peran guru yang dapat mempengaruhi semangat belajar seorang siswa (Syah, 2007) Guru mampu memotivasi siswanya untuk belajar lebih giat lagi untuk mencapai prestasi yang diharapkan dengan memilih model pembelajaran yang tepat dan sesuai denga karakter siswa. 
Pada proses pembelajaran tidak selamanya berjalan dengan baik. Masalah yang dihadapi oleh guru dalam model pembelajaran Brain Based Learning kurangnya waktu pembelajaran karena langkah pembelajaran model pembelajaran Brain Based Learning memiliki banyak langkah yang memakan waktu yang cukup lama dibandingkan dengan pembelajaran biasa. Untuk itu guru harus bisa memanfaatkan waktu semaksimal mungkin dan dalam pembelajaran matematika terletak pada pemilihan musik yang akan diputar ada pada kehidupan sehari-hari diberikan kepada siswa untuk memahami materi yang harus disesuaikan dengan karakter siswa. Berikut ini adalah suasana kegiatan belajar mengajar :

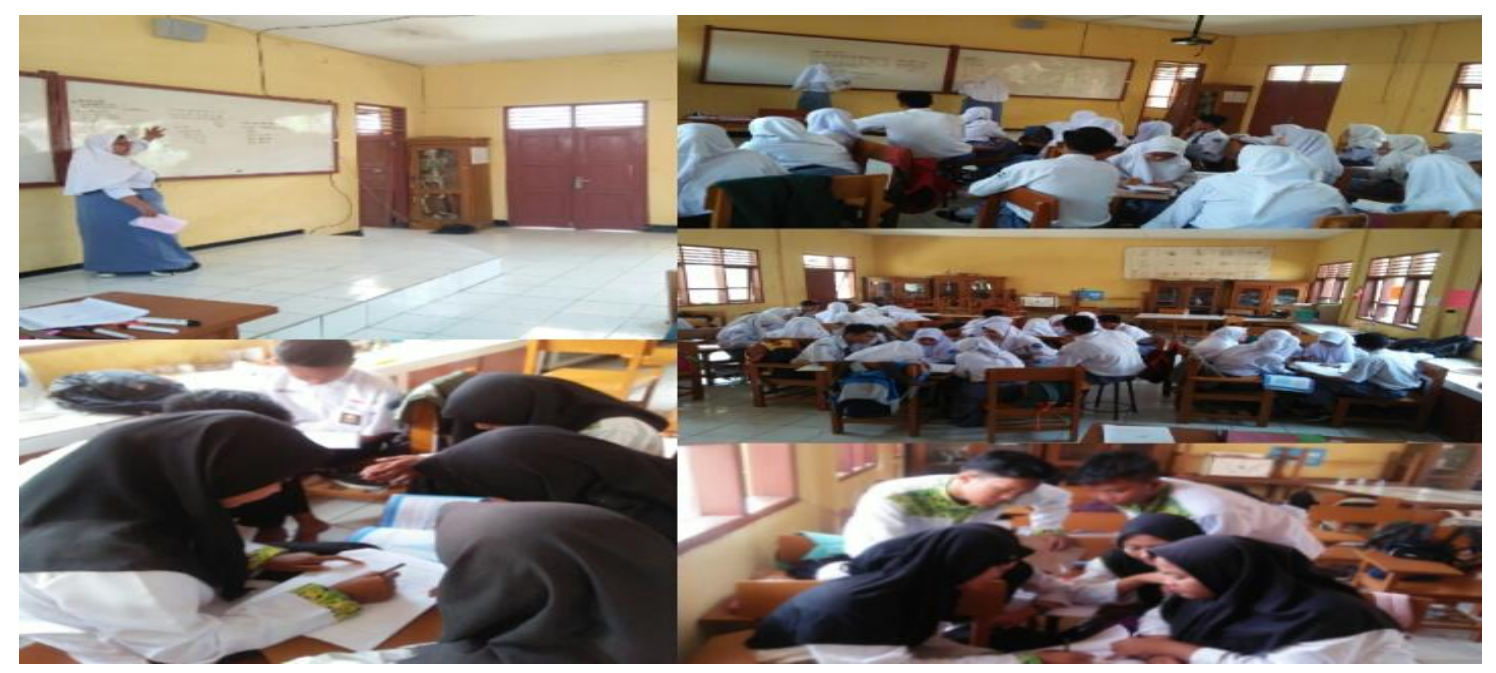

Gambar 1. Suasana Kegiatan Belajar Mengajar

Berdasarkan gambar diatas terlihat bahwa siswa sangat antusias dan berperan aktif dalam proses kegiatan belajar mengajar. Siswa tidak malu bertanya kepada guru saat ada yang ingin ditanyakan pada masalah dan penyelidikan permasalahan yang ada pada lembar kerja siswa. Siswa saling berdiskusi dan bertukar pendapat mengenai permasalahan yang ada pada lembar kerja siswa. Berani mempresentasikan hasil diskusinya dan pembelajaran berjalan dengan kondusif. Dengan demikian, siswa menggunakan belajar matematika dengan sebaik-baiknya.

Berdasarkan skala motivasi, siswa memiliki motivasi pada kategori baik terlihat hasilnya didominasi oleh persentase $51 \%-75 \%$. Dengan kata lain, siswa sudah memenuhi indikator motivasi belajar pada persentase dengan kategori baik. Indikator motivasi belajar menurut Abin (Hamdu dan Agustina, 2011), yaitu : (1) Durasi belajar, (2) Frekuensi belajar, (3) Presistensi dalam belajar, (4) Ketabahan, keuletan dan kemampuannya dalam menghadapi kegiatan dan kesulitan untuk mencapai tujuan, (5) Pengabdian dan pengorbanan untuk mencapai tujuan, (6) Tingkatan aspirasi siswa dalam belajar, (7) Tingkat kualifikasi prestasi belajar, (8) Arah sikapnya terhadap sasaran kegiatan.

\section{SIMPULAN}

Berdasarkan hasil temuan penelitian dan pembahasan, motivasi siswa terhadap pembelajaran matematika dengan model pembelajaran Brain Based Learning berada pada kriteria baik. Indikator motivasi belajar dengan kriteria sangat baik pada durasi kegiatan belajar berada pada kriteria sangat baik. Indikator pada kriteria baik pada presistensi kegiatan belajar, pengabdian dan pengorbanan, tingkatan aspirasi yang hendak dicapai dengan kegiatan yang dilakukan. Indikator pada kriteria cukup baik pada frekuensi kegiatan belajar; ketabahan, keuletan dan kemampuan dalam menghadapi kegiatan dan kesulitan, tingkatan kualifikasi prestasi, dan arah sikap terhadap sasaran kegiatan. 


\section{DAFTAR PUSTAKA}

Andriani, I.M. dan Ansari, B. I. 2016. Peningkatan kemampuan pemahaman dan motivasi siswa SMP melalui model missouri mathematics project (MMP) dengan menggunakan game matematika online. Jurnal didaktik matematika.3 (1), 55-63.

Arikunto, S. 2010. Prosedur Penelitian Suatu Pendekatan Praktik. Jakarta: Rineka Cipta.

Faidi, A. 2013. Tutorial Mengajar untuk Melejitkan Otak Kanan dan Kiri Anak. Yogyakarta: DIVA Press.

Hamdhu, G. dan Agustiana, L. 2011. Pengaruh Motivasi Belajar Siswa terhadap Prestasi Belajar IPA. Dalam jurnal UPI .[Online], Vol 12 (1), 7 halaman. Tersedia: jurnal.Upi.edu. [3 januari 2019].

Isro'i, N.F. dan Ghufron A. 2016. Pengaruh persepsi belajar siswa terhadap motivasi belajar matematika di sekolah SMAn 1 Curup Timur tahun ajaran 2015/2016. Jurnal educt. 2 (2). 107 131.

Pebrinovita, W. 2013. Pengaruh Kompetensi Profesional dan Pedagogik Guru Ekonomi terhadap Motivasi Belajar Siswa SMA. [Online]. Tersedia: http://repository.unri.ac.id.

Oktober 2019].

Riduwan. 2004. Metode dan Teknik Menyusun Tesis. Bandung : Alfabeta, Cetakan Pertama.

Sadirman, A. M. 2011. Interaksi dan Motivasi Belajar Mengajar. Semarang: Universitas Negeri Semerang.

Sukonco, H. dan Mahmudi, A. 2016. Pengaruh pendekatan Brain Based Learning terhadapkan kemampuan komunikasi matematis dan slelf efficacy siswa. Jurnal Pendidikan Matematika.11 (1). 11-24.

Syah, M. 2007. Psikologi Pendidikan. Jakarta: Rajawali Grafindo Persada.

Syamarro, N., Saluki, Winarso, W. 2015. Pengaruh Motovasi Dan Persepsi Siswa pada Matematika terhadap Prestasi Belajar Matematika Siswa Kelas VII di Mts. Dukuputang Kabupaten Cirebon(pokok bahasan kubus dan balok). Jurnal eduma. 4(2). 105-111.

Syarwan, R. Mukhni. Murni, D. 2014. Pengaruh pendekatan Brain Based Learning terhadapap kemampuan penalaran matematis siswa lelas VII SMP Islam Raudhatul Jannah Payakumbu . Jurnal pendidikan matematika. 3 (1). 29-34. 